\title{
METODE KOMUNIKASI SEMUT (KOMUSEM) UNTUK MENINGKATKAN KEAKTIFAN BELAJAR TRIGONOMETRI PESERTA DIDIK
}

\author{
Prayitno $^{1}$, Abdillah ${ }^{2}$ \\ ${ }^{1}$ SMA Negeri 3 Jombang \\ ${ }^{2}$ Jurusan Pendidikan Matematika IAIN Ambon \\ prayitno@sman3jombang.sch.id
}

\begin{abstract}
Abstrak
Penelitian ini bertujuan untuk mendeskripsikan penerapan metode komunikasi semut untuk meningkatkan keaktifan belajar trigonometri peserta didik kelas X IPS-4 SMA Negeri 3 Jombang tahun pelajaran 2013/2014. Penelitian ini merupakan penelitian tindakan sebagai upaya menguji cobakan ide-ide ke dalam praktek untuk memperbaiki atau merubah sesuatu agar memperoleh dampak nyata dari situasi. Adapun indikator keaktifan yang diamati meliputi: (1) data hasil pengamatan peserta didik dalam membentuk kelompok, (2) data hasil pengamatan peserta didik dalam menyampaikan ide atau pertanyaan, (3) data hasil pengamatan peserta didik dalam bekerja sama dengan peserta lain, dan (4) data hasil pengamatan peserta didik dalam mengikuti proses belajar mengajar (PBM) dan (5) data hasil pengamatan peserta didik dalam mencatat materi. Hasil penelitian ini menunjukkan bahwa penerapan metode komunikasi semut dapat meningkatkan keaktifan belajar trigonometri peserta didik kelas X IPS-4 SMA Negeri 3 Jombang tahun pelajaran 2013/2014. Hal ini dapat ditunjukkan dengan meningkatnya persentase hasil observasi keaktifan peserta didik yang meningkat dari siklus 1 ke siklus berikutnya

Kata kunci: Penerapan, metode komunikasi semut, keaktifan siswa
\end{abstract}

\begin{abstract}
This research aims to describe application of ants' communication to improve students' activeness when learn trigonometry on grade 10th in SMA Negeri 3 Jombang, academic year 2013/2014. This research is action reseach as an effort to make ideas in action to improve or change something to real effect. There are some indicators such as, 1) observation data when formed a group 2) observation data when student told idea or question 3) observation data when student collaborative with the other 3) observation data when student noted material. Result of this research shows that ants' communication can improve students' activeness when learn trigonometry on grade 10th in SMA Negeri 3 Jombang, academic year 2013/2014. It can be showed by the percetage progress when observed students' activeness from first cycle to the second cycle.
\end{abstract}

Keywords: application, ants' communication, students' activeness.

Sitasi: Prayitno, Abdillah. 2018. Metode Komunikasi Semut (Komusem) untuk Meningkatkan Keaktifan Belajar Trigonometri Peserta Didik. Matematika dan Pembelajaran, 6(2), 201-214 


\section{PENDAHULUAN}

Pada mata pelajaran matematika, biasanya metode yang digunakan oleh guru adalah metode konvensional (Zulyadaini, 2016). Guru dalam melaksanakan pembelajaran menggunakan lisan. Dari hal ini dapat dilihat bahwa keaktifan peserta didik kurang berperan, sehingga untuk berpikir kreatif pun peserta didik mengalami hambatan, selain itu metode ceramah ini menimbulkan rasa bosan pada peserta didik, sehingga metode ini dirasa kurang efektif (Akbar Taufik, 2018). Oleh karena itu dalam proses belajar mengajar perlu adanya pendekatan pembelajaran yang lebih efektif mampu menciptakan suasana lebih mengaktifkan peserta didik khususnya pada mata pelajaran matematika.

Untuk melibatkan peserta didik dalam pembelajaran secara aktif perlu dikembangkan suatu metode. Salah satu metode alternatif yaitu menerapkan bentuk pembelajaran kooperatif yang dapat meningkatkan pemahaman suatu konsep. Nur mengatakan dalam pembelajaran dengan kooperatif peserta didik dapat saling mengemukakan dan meluruskan miskonsepsi-miskonsepsi diantara mereka (Nur, 2004).

Keterlibatan peserta didik dalam pembelajaran menyebabkan terjadinya komunikasi yang multi arah antar peserta didik seperti halnya seekor semut yang selalu berhenti dan berkomunikasi jika bertemu dengan semut yang lainnya, hal ini sangat menarik untuk dikaji sebagai metode pembelajaran. Semut begitu peduli terhadap sesamanya. Semut memiliki etos kerja yang tinggi, kesabaran dan kekompakan. Kita sering melihat kekompakan semut dalam berjalan, bergotong royong mencari dan mengangkut makanan (Anita, 2017).

Salah satu kisah yang menarik di dalam Al-Qur'an adalah kisah mengenai Nabi Sulaiman yang mendengar perkataan semut yang memperingatkan akan kedatangan Nabi Sulaiman dan tentaranya yang mendekati sarang mereka. Dikisahkan salah satu semut dalam kawanan tersebut memperingatkan kawankawannya untuk segera kembali ke sarang-sarang mereka agar tidak terinjak oleh tentara nabi Sulaiman. Kisah tersebut tertuang dalam dua ayat di surah An-Naml (27) ayat 18-19 yang mengatakan : [27:18] Hingga apabila mereka sampai di 
lembah semut berkatalah seekor semut: Hai semut-semut, masuklah ke dalam sarang-sarangmu, agar kamu tidak diinjak oleh Sulaiman dan tentaranya, sedangkan mereka tidak menyadari"; [27:19] maka dia (Sulaiman) tersenyum dengan tertawa karena (mendengar) perkataan semut itu. Dan dia berdoa: "Ya Tuhanku, berilah aku ilham untuk tetap mensyukuri nikmat-Mu yang telah Engkau anugerahkan kepadaku dan kepada dua orang ibu bapakku dan untuk mengerjakan amal saleh yang Engkau ridai; dan masukkanlah aku dengan rahmatMu ke dalam golongan hamba-hamba-Mu yang saleh".

Orang yang membaca kedua ayat di atas mungkin akan bertanya, apa maksudnya Allah mengungkapkan kisah tersebut di ayat Al-Qur'an. Suatu kisah yang sepele dan tidak pernah ada di kitab-kitab sebelumnya. Banyak yang menganggap cerita di atas hanyalah dongeng, karena yang dikatakan dapat "mendengar" perkataan sang semut hanyalah nabi Sulaiman.

Al-Qur'an An-Naml berarti "Kawanan semut (semut dalam bentuk jamak)". Dari 93 ayat yang ada di dalam surah ini, kata "semut" hanya di sebutkan di dalam satu ayat, yaitu ayat 18. Jika di ayat 19 di atas, sepertinya terlihat ada kata "semut" di sana, tapi sebenarnya "perkataan semut itu" terjemahan literalnya adalah "perkataannya (sang semut)". Nama surah ini di berikan judul "Kawanan semut", walaupun dari 93 ayat, hanya 1 ayat yang menyebutkan tentang semut. Hal ini mengindikasikan ada sesuatu yang penting tentang kisah semut yang dikisahkan dalam ayat di atas.

Ilmu pengetahuan saat ini mengungkapkan bahwa semut menggunakan komunikasi kimia dengan cara memberikan alarm atau peringatan kepada kelompoknya sehingga terjadi pertukaran informasi secara cepat. Zat-zat kimia ini dikeluarkan oleh kelenjar-kelenjar di dalam semut, di mana kebanyakan dari jenis spesies semut, zat-zat ini di hasilkan dengan kadar yang berbeda-beda oleh kelenjar mandibula dan juga kelenjar racun, tergantung jenis situasi yang dihadapi. 
Holldobler seorang penyelidik di Harvard University Press, pernah mengadakan percobaan dengan semut dimana ia mengambil seekor semut lalu diletakkan dalam tempat yang berisi makanan. Kemudian semut lain diletakkan dalam tempat yang berisi semut-semut musuh. Kemudian kelakuan kedua semut ini diamati terutama ketika bertemu dengan semut lain dalam perjalanannya. Dari penyelidikan itu, Schneirla menyimpulkan bahawa zat kimia yang dikeluarkan dari makanan ataupun dari musuh semut akan melekat pada semut itu. Ketika bertemu dengan semut lain, semut ini akan saling menyapa (bersentuhan). Maka, dengan saling menyapa inilah zat kimia dari semut tersebut akan memberi tau rekannya (melalui antena di kepala semut) apakah di lingkungan sekitarnya ada makanan atau ada musuh (Bert Holldobler, 1990).

\section{Pembelajaran Metode Komunikasi Semut (Komusem)}

Istilah Komusem merupakan singkatan dari komunikasi semut, sedangkan metode komusem adalah suatu metode pembelajaran yang dirancang dengan diilhami oleh kenyataan pada dunia semut yaitu setiap bertemu dengan semut lainnya maka semut akan berhenti sejenak dan saling berkomunikasi. Hal tersebut yang menjadi inspirasi Peneliti untuk menganalisis tahap-tahap dalam komunikasi semut menjadi tahapan dalam pembelajaran yang peneliti namakan metode komunikasi semut.

Adapun konversi tahap-tahap komunikasi semut terhadap tahap-tahap dalam metode komusem adalah sebagai berikut:

\begin{tabular}{|c|c|c|}
\hline No. & Tahap-tahap komunikasi semut & Tahap-tahap metode komusem \\
\hline 1. & $\begin{array}{l}\text { Tahap } 1 \\
\text { Tahap lerting dimana semut meminta } \\
\text { perhatian kepada semut yang lain. }\end{array}$ & $\begin{array}{l}\text { Tahap } 1 \\
\text { Tahap orientasi, dalam tahap ini guru } \\
\text { memberikan orientasi pembelajaran }\end{array}$ \\
\hline 2. & $\begin{array}{l}\text { Tahap } 2 \\
\text { semut-semut berlari dengan cepat dan acak, } \\
\text { serta mengubah arah. } \\
\text { Tahap } 3\end{array}$ & $\begin{array}{l}\text { Tahap } 2 \\
\text { Tahap Pengelompokan, dalam tahap ini } \\
\text { pembelajaran dibagi dalam kelompok- } \\
\text { kelompok kecil ( } 5 \text { orang) }\end{array}$ \\
\hline 3. & $\begin{array}{l}\text { Tahap attraction dan stopping dimulai } \\
\text { di mana perhatian para semut diarahkan } \\
\text { kepada source atau sumber bahaya, dalam } \\
\text { hal ini adalah Sulaiman dan tentaranya. }\end{array}$ & $\begin{array}{l}\text { Tahap } 3 \\
\text { Tahap Komunikasi, dalam tahap ini } \\
\text { masing-masing pioner dalam kelompok } \\
\text { memimpin diskusi kelompoknya, } \\
\text { kemudian pioner berpindah ke kelompok } \\
\text { lain untuk mengkomunikasikan hasil } \\
\text { diskusi kelompoknya. } \\
\text { Tahap } 4\end{array}$ \\
\hline
\end{tabular}




\begin{tabular}{|l|l|lrr|}
\hline dalam tahap ini, semut-semut itu di & Tahap evaluasi, dalam tahap ini \\
perintahkan hold atau tunggu untuk & perwakilan dari masing-masing anggota \\
bersama-sama menentukan jenis pertahanan & kelompok ditunjuk & untuk \\
apa yang harus mereka buat untuk & mempresentasikan materi & yang \\
mempertahankan diri dan sarang mereka. & diperolehnya dari seorang pioner & \\
\hline
\end{tabular}

Tahap orientasi, dalam tahap ini peneliti memberikan orientasi pembelajaran yang meliputi penyampaian tentang $\mathrm{SK}$, KD, tujuan pembelajaran dan metode yang akan digunakan dalam pembelajaran.

Tahap Pengelompokan, dalam tahap ini pembelajaran dibagi dalam kelompok-kelompok kecil yang terdiri dari 5 orang. Penentuan anggota kelompok didasarkan pada hasil ulangan harian peserta didik untuk menjadi pioneer dan pemerataan jenis kelamin. Dalam penelitian ini, anggota kelompok diberi kode sesuai dengan nomor urut absen peserta didik. Sedangkan masing-masing kelompok dipimpin oleh seseorang yang diberi nama pioneer yang mempunyai tugas untuk memimpin diskusi kelompok pada kelompoknya.

Tahap Komunikasi, dalam tahap ini masing-masing pioner dalam kelompoknya memimpin diskusi kelompok, kemudian pioner berpindah/berjalan menuju kelompok lain untuk mengkomunikasikan hasil diskusi kelompoknya. Hal ini dilakukan sebanyak 3 sampai 4 putaran atau perpindahan pioner.

Tahap evaluasi, dalam tahap ini perwakilan dari masing-masing anggota kelompok ditunjuk untuk mempresentasikan materi atau permasalahan yang diperolehnya dari penjelasan beberapa pioner. Selain itu evaluasi dapat juga berupa pemberian pertanyaan kepada anggota kelompok sekaligus sebagai penguatan materi pada pembelajaran tersebut

Trigonometri merupakan bagian dari materi pokok matematika yang manfaatnya dalam kehidupan sehari-hari sangat penting bagi kita. Namun demikian sebagian peserta didik kurang suka dengan materi tersebut, hal ini disebabkan oleh banyak factor yang salah satunya adalah peserta didik telah mendapat informasi yang salah dari masyarakat sekelilingnya bahwa matematika itu ilmu yang sulit sehingga peserta didik enggan untuk mempelajari lebih mendalam (Rully Anggraini, 2016). 
Peserta didik kelas X IPS-4 merupakan bagian dari kelas X SMA Negeri 3 Jombang yang proses rekrutmennya melalui saringan yang sangat ketat sehingga mereka yang diterima mempunyai kemampuan dan kecerdasan yang tinggi. Hal ini secara logika dengan kemampuan dan kecerdasan yang tinggi maka keaktifan peserta didik dalam mengikuti proses pembelajaran juga sangat tinggi, namun pada kenyataannya keaktifan peserta didik dalam mengikuti proses pembelajaran masih rendah dan mengakibatkan banyaknya peserta didik yang tidak tuntas belajarnya atau tidak mencapai KKM matematika yaitu 75 .

\section{METODE}

Jenis penelitian yang dilakukan adalah penelitian tindakan. (Riyanto, 2007) menyatakan bahwa penelitian tindakan merupakan upaya menguji cobakan ide-ide ke dalam praktek untuk memperbaiki atau merubah sesuatu agar memperoleh dampak nyata dari situasi. Pendekatan yang digunakan dalam penelitian ini yakni pendekatan kualitatif deskriptif yakni mendeskripsikan penerapan metode komusem untuk meningkatkan keaktifan belajar matematika peserta didik kelas X IPS-4 SMA Negeri 3 Jombang tahun pelajaran 2013/2014.

Data yang dihimpun dalam penelitian ini terdiri dari: (1) data hasil pengamatan peserta didik dalam membentuk kelompok, (2) data hasil pengamatan peserta didik dalam menyampaikan ide atau pertanyaan, (3) data hasil pengamatan peserta didik dalam bekerja sama dengan peserta lain, dan (4) data hasil pengamatan peserta didik dalam mengikuti proses belajar mengajar (PBM) dan (5) data hasil pengamatan peserta didik dalam mencatat materi yang diperoleh pada pertemuan tersebut. 


\section{HASIL DAN PEMBAHASAN}

Berdasarkan temuan-temuan penelitian pada siklus 1, pada bagian ini penulis membahas atau memberikan solusi untuk mengatasi masalah-masalah tersebut guna dijadikan pertimbangan untuk memperbaiki pembelajaran pada siklus 2 .

Adapun pembahasan masing-masing temuan penelitian pada siklus 1 adalah sebagai berikut:

1. Pada saat pembentukan kelompok, kesadaran peserta didik untuk membentuk kelompok sangat rendah.

Langkah-langkah yang dilakukan peneliti meliputi:

a. Memberikan nasehat tentang pentingnya menghargai kesepakatan bersama dalam hal ini adalah membentuk kelompok yang diberi waktu 5 menit.

b. Melakukan pendekatan kepada peserta didik yang tidak membentuk kelompok sesuai dengan waktu yang diberikan agar tidak mengulangi

2. Kurangnya kepedulian peserta didik untuk menyampaikan ide/pertanyaan pada saat proses pembelajaran berlangsung.

Langkah-langkah yang dilakukan peneliti meliputi:

a. Secara umum peneliti menghimbau kepada seluruh peserta didik agar tidak minder untuk menyampaikan ide atau pertanyaan jika merasa belum mengerti tentang materi yang dipelajarinya.

b. Melakukan pendekatan kepada peserta didik yang mempunyai sifat pendiam untuk memberikan motivasi agar selalu percaya diri untuk bertanya atau menyampiakan ide-idenya.

c. Memberi teguran pada peserta didik yang membicarakan hal-hal di luar materi yang dipelajarinya agar fokus pada materi dan mau bertanya atau menyampaikan ide-idenya tentang materi yang sedang dibahsnya.

d. Peneliti memberikan instrumen observasi kepada pioner di masing-masing kelompok untuk mencatat temannya yang bertanya atau menyampaikan ide-idenya.

3. Rata-rata peserta didik masih menonjolkan rasa egois yang tinggi sehinga kerjasama antar peserta didik tidak berjalan dengan baik.

Langkah-langkah yang dilakukan peneliti meliputi: 
a. Memberikan masukan tentang pentingnya bekerjasama dalam tim atau kelompok dan memberikan motivasi agar tidak egois dalam diskusi kelompok.

b. Melakukan pendekatan kepada anak yang egois dan memberikan pengertian bahwa kepampuan anak tidak sama sehingga dibutuhkan kerjasama untuk mencapai tujuan yang diinginkan.

4. Banyak peserta didik yang tidak mencatat materi hasil pembelajaran dengan berbagai alasan

Langkah-langkah yang dilakukan peneliti meliputi:

a. Menanyakan penyebabnya peserta didik tidak mencatat.

b. Memberi teguran kepada peserta didik yang tidak mencatat agar tidak mengulangi lagi pada pembelajaran berikutnya.

c. Meminjami bolpoin kepada anak yang tidak menulis karena tidak membawa alat tulis.

d. Memberi motivasi kepada peserta didik agar mencatat materi pelajaran yang dibahasnya sebagai bahan atau bekal untuk belajar mempersiapkan ulangan.

Berdasarkan hal-hal yang dilakukan oleh peneliti tersebut di atas, diharapkan pada pembelajaran siklus ke-2 terjadi perubahan-perubahan kearah yang baik guna tercapainya tujuan pembebelajaran yang telah direncanakan.

c. kembali pada siklus berikutnya.

Adapun pembahasan masing-masing temuan penelitian pada siklus 2 adalah sebagai berikut:

5. Peningkatan persentase peserta didik dalam membentuk kelompok meningkat Langkah-langkah yang dilakukan peneliti meliputi:

a. Memberikan apresiasi dan pujian kepada pesera didik atas perubahan sikap yang dilakukan sehingga pembentukan kelompok dapat dilakukan dengan baik. 
b. Melakukan pendekatan kepada peserta didik yang masih membentuk kelompok belum sesuai dengan waktu yang diberikan agar tidak mengulangi kembali pada siklus berikutnya.

6. Partisipasi peserta didik untuk menyampaikan ide/pertanyaan masih rendah walaupun sudah peneliti beri nasehat ataupun motivasi

Langkah-langkah yang dilakukan peneliti meliputi:

a. Menugasi pioner untuk memberikan kesempatan lebih banyak kepada anggota kelompoknya yang belum menyampaikan ide atau pertanyaan.

b. Memberikan reward kepada kelompok yang paling aktif dalam mengikuti proses pembelajaran.

c. memberi pertanyaan secara individu agar peserta didik terispirasi untuk menjawabnya dan berlatih untuk menyampaikan ide atau pertanyaan kepada siapapun.

7. Kepedulian peserta didik untuk bekerjasama dan mengikuti proses belajar mengajar dengan tertib sudah bagus, hal ini ditunjukkan dengan meningkatnya persentase dari siklus 1 ke siklus 2 .

Dalam hal ini peneliti tetap selalu memberikan motivasi agar peserta didik tetap kompak dan bekerjasama dalam memecahkan masalah yang mereka hadapi.

8. Terdapat beberapa peserta didik yang mempunyai sifat pendiam dan motivasi belajarnya rendah.

Langkah-langkah yang dilakukan peneliti meliputi:

a. Untuk peserta didik yang bersifat pendiam, maka dilakukan pendekatan secara individu dan mengajaknya mengobrol dengan harapan tidak minder dan nantinya terbiasa untuk mengungkapkan sesuatu kepada orang lain.

b. Untuk peserta didik yang motivasi belajarnya rendah, dilakukan pendekatan secara individu untuk mengetahui penyebabnya kemudian peneliti memberikan saran sebagai solusi dari permasalahan yang dihadapi sehingga motivasi belajarnya bisa meningkat. 
9. Kepedulian peserta didik untuk mencatat materi pelajaran masih kurang, hal ini ditunjukkan dengan menurunnya persentase peserta didik yang mencatat materi pelajaran.

Langkah-langkah yang dilakukan peneliti meliputi:

a. Melakukan pendekatan kepada anak yang tidak mau mencatat untuk mencari tahu penyebab mereka tidak mencatat.

b. Memberikan tugas untuk mencatat materi dirumah dengan jalan pinjam catatan temannya.

Adapun pembahasan masing-masing temuan penelitian pada siklus 3 adalah sebagai berikut

1. Secara umum pembelajaran berjalan dengan baik dan menyenangkan

2. Peserta didik merasa senang dan bangga diberi kesempatan menjadi tutor sebaya

3. Semua peserta didik mencatat materi pelajaran

4. Masih dibutuhkan pendekatan intensif kepada beberapa peserta didik yang mempunyai sifat pendiam untuk selalu berani menyampaikan ide atau pertanyaan pada saat proses pembelajaran berlangsung.

Sesuai dari hasil temuan pada siklus 3, peneliti memberikan apresiasi dan pujian kepada semua peserta didik atas perannya sehingga pembelajaran dengan menggunakan metode komusem dapat berjalan dengan baik dan menyenangkan.

Selain dari itu, hasil temuan tersebut dapat dijadikan dasar oleh peneliti dalam menentukan keputusan untuk menghentikan penelitian pada siklus ke-3 karena semua indicator keaktifan peserta didik dalam mengikuti proses pembelajaran sudah dilakukan dengan baik atau dengan kata lain keaktifan peserta didik meningkat dengan menggunakan metode pembelajaran komusem. Walaupun demikian pendekatan kepada masing-masing individu tetap perlu dilakukan guna menumbuhkan rasa percaya diri dan mempunyai motivasi belajar yang tinggi untuk mencapai tujuan yang mereka inginkan.

Hal ini sejalan dengan (Nur, 2004) mengatakan bahwa pembelajaran kooperatif mengacu pada metode pembelajaran dimana peserta didik bekerja 
bersama dalam kelompok kecil saling membantu dalam belajar dan (Sagala, 2007) mengatakan di dalam kelas kooperatif peserta didik belajar bersama dalam kelompok-kelompok kecil yang terdiri 4-6 orang yang sederajat tetapi heterogen, kemampuan, jenis kelamin dan satu sama lainsaling membantu. Tujuan dibentuknya kelompok tersebut adalah untuk memberikan kesempatan kepada semua peserta didik untuk dapat terlibat secara aktif dalam proses berpikir dan kegiatan belajar.

Ciri-ciri pembelajaran kooperatif meliputi: (a) setiap anggota memiliki peran, (b) terjadi interaksi langsung antar anggota, (c) setiap anggota bertanggung jawab atas belajarnya, (d) guru membantu peserta didik dalam mengembangkan ketrampilan interpersonal kelompok, (e) guru hanya berinteraksi dengan kelompok saat diperlukan

Sekolah merupakan tempat untuk mengembangkan aktivitas. Berbagai macam jenis aktivitas yang dapat dilakukan peserta didik di sekolah, aktivitas peserta didik tidak hanya cukup mendengarkan dan mencatat yang biasa dilakukan disekolah-sekolah tradisional. Aktivitas peserta didik ialah kegiatan yang dilakukan oleh peserta didik selama proses belajar mengajar. Pembelajaran yang efektif adalah pembelajaran yang menyediakan kesempatan belajar sendiri atau melakukan sendiri. (Sardiman, 2007) mengemukakan bahwa bentuk aktivitas peserta didik meliputi:

1. visual activities, meliputi membaca, memperhatikan gambar, demonstrasi, percobaan, mengamati pekerjaan orang lain

2. oral activities, meliputi bertanya, memberi saran, mengeluarkan pendapat, wawancara, diskusi, interupsi

3. listening activities, meliputi mendengarkan penjelasan, diskusi, musik, pidato

4. writing activities, meliputi mencatat, menulis laporan, mengerjakan soal, dan sebagainya

5. drawing activities, meliputi menggambar, membuat grafik, membuat diagram

6. motor activities, meliputi melakukan percobaan, membuat konstruksi, 
model mereparasi, bermain, berkebun, berternak

7. mental activities, meliputi menanggapi, memecahkan soal, menganalisis, melihat hubungan, mengambil keputusan

8. emotional activities, meliputi menaruh minat, merasa bosan, gembira, bersemangat, bergairah, berani, tenang, gugup.

Berdasarkan uraian aktivitas peserta didik tersebut, penulis menekankan pada aktivitas peserta didik, khususnya pada visual, oral, listening, writing, mental, dan emotional activies. Sesuai dengan bentuk-bentuk aktivitas peserta didik tersebut, dalam penelitian ini aspek aktivitas yang diamati antara lain: (1) memperhatikan peserta didik dalam membentuk kelompok, (2) memperhatikan peserta didik dalam menyampaikan idea atau pertanyaan, (3) memperhatikan peserta didik dalam bekerjasama dengan peserta didik lain, (4) mengikuti proses belajar mengajar dengan tertib dan baik dan (5) memperhatikan peserta didik dalam mencatat materi hasil pembelajaran.

Kejadian tersebut juga sesuai (Silberman, 2006) bahwa waktu khusus tiap harinya harus dialokasikan agar peserta didik saling membantu belajar matematika, bahasa atau pelajaran lainnya, baik satu-satu atau dalam kelompok kecil. Tutor Sebaya merupakan salah satu strategi pembelajaran untuk membantu memenuhi kebutuhan peserta didik. Ini merupakan pendekatan kooperatif bukan kompetitif. Rasa saling menghargai dan mengerti dibina di antara peserta didik yang bekerja bersama.

Tutor sebaya akan merasa bangga atas perannya dan juga belajar dari pengalamannya. Hal ini membantu memperkuat apa yang telah dipelajari dan diperoleh atas tanggung jawab yang dibebankan kepadanya. Ketika mereka belajar dengan "tutor sebaya", peserta didik juga mengembangkan kemampuan yang lebih baik untuk mendengarkan, berkonsentrasi, dan memahami apa yang dipelajari dengan cara yang bermakna. Penjelasan tutor sebaya kepada temannya memungkinkan lebih berhasil dibandingkan guru. Peserta didik melihat masalah dengan cara yang berbeda dibandingkan orang dewasa dan mereka menggunakan bahasa yang lebih akrab (Nurhayati, 2010). 


\section{KESIMPULAN DAN SARAN}

Berdasarkan pembahasan pada penelitian ini dapat disimpulkan bahwa penerapan metode komunikasi semut dapat meningkatkan keaktifan belajar matematika peserta didik kelas X IPS-4 SMA Negeri 3 Jombang tahun pelajaran 2013/2014. Hal ini dapat ditunjukkan dengan meningkatnya persentase hasil observasi keaktifan peserta didik yang meningkat dari siklus 1 ke siklus berikutnya

Pembelajaran dengan menggunakan metode komunikasi semut ternyata mendapat sambutan baik dari para peserta didik yang merasa lebih menyenangkan dan menarik terutama bagi pioneer karena mereka mendapat tantangan untuk bisa menjelaskan materi dengan baik kepada teman-teman sebayanya. Untuk itu perlu dilakukan lebih lanjut penelitian yang terkait.

\section{DAFTAR RUJUKAN}

Akbar Taufik, S. (2018). Efektivitas penerapan metode pembelajaran Hypnoteaching terhadap hasil belajar matematika. Histogram: Jurnal Pendidikan Matematika, 183-194.

Anita. (2017). Perilaku Semut Rangrang (Oechophylla Smaragdina) Dalam Membangun Sarang Sebagai Referensi Yang Bernilai Islami Pada Mata Kuliah Entomologi. Banda Aceh: Fakultas Tarbiyah Dan Keguruan, Universitas Islam Negeri ArRaniry Darussalam.

Bert Holldobler, E. O. (1990). The Ants. London: Harvard University Press.

Nur, M. (2004). Pengajaran Berpusat Kepada Peserta didik dan Pendekatan Konstruktivis dalam Pengajaran. Surabaya: Universitas Negeri Surabaya.

Nurhayati. (2010). Manajemen Proyek. Jogjakarta: Graha Ilmu.

Riyanto, Y. (2007). Metodologi Penelitian Pendidikan Kualitatif dan Kuantitatif. Surabaya: University Press.

Rully Anggraini, R. W. (2016). Pengembangan Bahan Ajar Materi Trigonometri Berbantuan Software Imindmap Pada Siswa Di SMA. Jurnal Al-Jabar, 39-47.

Sagala, S. (2007). Konsep dan Makna Pembelajaran. Bandung: Alfabeta.

Sardiman, A. (2007). Interaksi dan Motivasi Belajar. Jakarta: PT Raja Gravindo. 
Silberman, M. L. (2006). Active Learning 101 Cara Bealajar Siswa Aktif. Bandung: Nuansa.

Zulyadaini. (2016). Perbandingan Hasil Belajar Matematika Model Pembelajaran Kooperatif Tipe Coop-Coop dengan Konvensional. Jurnal Ilmiah Universitas Batanghari Jambi, 153-158. 